\title{
SUBSTITUSI SEBAGIAN PUPUK KIMIA DENGAN PUPUK ORGANIK HAYATI PADA JAGUNG (Zea mays)
}

\section{Partly Substitution of Chemical Fertilizer with Bio-organic Fertilizer on Maize (Zea mays)}

\author{
Syah Deva Ammurabi1), Iswandi Anas ${ }^{2)^{*}}$ dan Budi Nugroho') \\ 1) Program Studi Bioteknologi Tanah dan Lingkungan, Sekolah Pascasarjana, IPB University, Kampus IPB \\ Darmaga, Bogor, 16680 \\ 2) Departemen Ilmu Tanah dan Sumberdaya Lahan, Fakultas Pertanian, IPB University, J1. Meranti Kampus IPB \\ Dramaga Bogor 16680
}

\begin{abstract}
High amount of chemical fertilizer application simultanously causes soil degradation and environmental pollution. Bioorganic fertilizer application increas nutrient availability, improve soil properties, promote plant growth and increase plant yield. This study aimed to understand effects of chemical fertilizer substitution with bio-organic fertilizer on growth, uptake of $N, P, K$, and agronomic efficiency of maize in vegetative phase. Pot experiment was conducted at IPB Cikabayan Experimental Station, Dramaga, Bogor. Soil analyses was conducted at the Department of Soil Science and Land Resource Laboratory, Faculty of Agriculture, Bogor Agricultural University (IPB). Randomized Block Design with single factor was used in this experiment. The treatments were Control, $\mathrm{POH}$ (bio-organic fertilizer only), $\mathrm{POH}+50 \%(\mathrm{NPK}), \mathrm{POH}+100 \%(\mathrm{NPK}), 50 \%$ (NPK), and 100\% (NPK). Bisma maize variety was used as plant indicator. Five weeks after planting, the biomass (shoot and roots) were harvested. NPK uptake was performed to shoot samples. Results showed that bio-organic fertilizer application reduced the rate of chemical fertilizer by $50 \%$ and signifiantly increased $N, P$, and $K$ uptake. Combination between bio-organic fetilizer and 50\% chemical fertilizer had the highest agronomic efficiency. Bio-organic fertilizer substitute 50\% chemical fertilizer of maize.
\end{abstract}

Keywords: Dosage, efficiency, fertilization

\section{ABSTRAK}

Penggunaan pupuk kimia dengan takaran tinggi terus-menerus menyebabkan kerusakan tanah dan pencemaran lingkungan. Aplikasi pupuk organik hayati $(\mathrm{POH})$ atau dikenal dengan bio-organic fetilizer, dapat meningkatkan ketersediaan hara, memperbaiki sifat-sifat tanah, memacu pertumbuhan dan produksi tanaman. Penelitian ini bertujuan untuk mengetahui pengaruh substitusi sebagian takaran pupuk kimia dengan $\mathrm{POH}$ terhadap pertumbuhan, serapan N, P, dan K, serta efisiensi agronomi pemupukan jagung. Percobaan pot dilakukan di Kebun Percobaan Cikabayan, Kampus IPB Dramaga, Bogor. Analisis laboratorium dilakukan di Laboratorium Departemen Ilmu Tanah dan Sumberdaya Lahan, Fakultas Pertanian, Kampus IPB Darmaga, Bogor. Rancangan Acak Kelompok dengan faktor tunggal digunakan dalam percobaan ini. Perlakuan percobaan terdiri dari Kontrol, $\mathrm{POH}, \mathrm{POH}+50 \%(\mathrm{NPK}), \mathrm{POH}+100 \%(\mathrm{NPK}), 50 \%(\mathrm{NPK})$, dan $100 \%$ (NPK). Jagung varietas Bisma digunakan sebagai tanaman indikator. Setelah lima minggu setelah tanam, biomassa di panen untuk penimbangan bobot kering tajuk dan bobot kering akar. Jaringan tajuk dianalisis untuk menetapkan serapan N, P, dan K. Hasil penelitian menunjukkan bahwa pemberian pupuk organik hayati mampu mengurangi 50\% kebutuhan pupuk kimia dan meningkatkan serapan $\mathrm{N}$, P, dan $\mathrm{K}$. Kombinasi POH dengan 50\% (NPK) menghasilkan efisiensi agronomi tertinggi. POH mampu mensubstitusi 50\% kebutuhan NPK jagung.

Kata kunci: Dosis, efisiensi, pemupukan

\section{PENDAHULUAN}

Pemupukan merupakan salah satu aspek penting dalam pemeliharaan tanaman. Aplikasi pupuk kimia menjamin tercukupinya kebutuhan hara bagi tanaman. Pada awalnya, penggunaan pupuk kimia meningkatkan produktivitas tanaman secara nyata. Penggunaan pupuk kimia dianggap lebih praktis dibandingkan pupuk organik karena kebutuhannya lebih sedikit pada dosis hara yang sama, sehingga penggunaan pupuk organik mulai ditinggalkan. Namun, peningkatan produksi semakin melandai dan terus menurun (Anas, 2016). Menurut Li et al., (2017), aplikasi pupuk NPK tanpa pemberian bahan organik hanya mampu meningkatkan produksi jagung secara signifikan pada 12 tahun pertama. Penggunaan pupuk kimia dengan takaran tinggi terus-menerus menyebabkan pencemaran tanah, air, dan udara serta kerusakan pada tanah, seperti rusaknya struktur tanah; rusaknya keanekaragaman hayati biota tanah; pencucian hara berlebihan; pencemaran air; dan sebagainya (Savci, 2012; Anas, 2016). Penggunaan pupuk kimia yang dikombinasikan dengan pupuk organik hayati merupakan pilihan agar produksi dapat dipertahankan, kerusakan tanah dapat dihindari, dan pencemaran tanah dapat dikurangi.

Permasalahan ketersediaan hara dapat diatasi melalui aplikasi pupuk organik hayati. Pupuk organik hayati 
merupakan pupuk organik yang diperkaya dengan mikrob fungsional. Aplikasi pupuk organik hayati mampu meningkatkan ketersediaan hara, meningkatkan ketahanan terhadap hama dan penyakit, memacu pertumbuhan tanaman, serta memperbaiki sifat tanah (Anas, 2016). Penggunaan pupuk ini dapat dikombinasikan dengan penggunaan pupuk kimia. Kombinasi tersebut mampu meningkatkan efisiensi pemupukan kimia melalui peningkatan serapan hara dan biomassa tanaman (Setiyowati, 2011; Kalhapure et al., 2013). Hal ini tentu dapat mengurangi kebutuhan pupuk kimia, mengurangi biaya pemupukan, memperbaiki sifat-sifat tanah, sekaligus memacu pertumbuhan dan produksi tanaman.

Penelitian ini bertujuan untuk (1) mengetahui pengaruh substitusi sebagian pupuk kimia dengan pupuk organik hayati terhadap pertumbuhan jagung; (2) mengetahui pengaruh substitusi pupuk kimia dengan pupuk organik hayati terhadap serapan N, P, dan K jagung; dan (3) mengetahui pengaruh substitusi pupuk kimia dengan pupuk organik hayati terhadap efisiensi agronomi pemupukan jagung.

\section{BAHAN DAN METODE}

Penelitian berlangsung antara bulan Mei 2017 Februari 2018. Penelitian dilakukan di Kebun Percobaan Cikabayan, Kampus IPB Darmaga, Bogor untuk percobaan penanaman jagung dalam pot (polibag). Media tanam Latosol diambil di lokasi setempat. Analisis sifat kimia, kadar N, P, K jaringan tanaman, dan analisis sifat biologi tanah dilakukan di Laboratorium Kimia dan Kesuburan Tanah dan Laboratorium Bioteknologi Tanah, Departemen Ilmu Tanah dan Sumberdaya Lahan, Fakultas Pertanian, Institut Pertanian Bogor.

Benih jagung varietas Bisma diperoleh dari Balai Besar Litbang Bioteknologi dan Sumberdaya Pertanian (BB Biogen), pupuk organik hayati (bio-organic fertilizer) BIOST, Urea, SP-36, KCl, dan pupuk kandang sapi. Adapun mikrob yang terkandung dalam pupuk organik hayati BIOST adalah bakteri Azotobacter, Azospirillum, dan mikroba pelarut fosfat.

\section{Rancangan Percobaan}

Percobaan menggunakan Rancangan Acak Kelompok dengan faktor tunggal. Perlakuan terdiri dari kombinasi pupuk organik hayati $(\mathrm{POH})$ dengan pupuk kimia (N, P, dan K) sebanyak 6 perlakuan (Tabel 1). Percobaan diulang 3 kali hingga diperoleh 18 satuan percobaan. Setiap satuan percobaan terdiri dari tiga polibag yang masing-masing ditanam dua benih jagung.

\section{Prosedur Percobaan}

Contoh tanah Latosol Dramaga diambil dari Kebun Percobaan Cikabayan diambil secara komposit pada kedalaman $0-20 \mathrm{~cm}$, dikering udarakan, dihaluskan hingga lolos saringan $5 \mathrm{~mm}$, ditimbang seberat $5 \mathrm{~kg}$ bobot kering mutlak (BKM), dimasukkan ke dalam polibag, dan digunakan sebagai media tanam. Tanah tersebut diberi kapur kalsit dengan dosis 1 x Al dd dan pupuk kandang sebanyak 5 gram per kg tanah, kemudian tanah dan kapur dicampur secara merata. Tanah diinkubasi selama satu minggu dengan kadar air kapasitas lapang. Pemberian pupuk kimia dan pupuk organik hayati $(\mathrm{POH})$ dilakukan pada saat tanam dengan dosis yang tertera pada Tabel 1 dengan cara ditabur dan dicampur secara merata. Polibag berukuran $30 \mathrm{~cm}$ x $30 \mathrm{~cm}$ digunakan sebagai wadah tanam. Benih jagung varietas Bisma ditanam sebanyak 4 butir per polibag. Setelah satu minggu, dilakukan penjarangan menjadi dua tanaman per polibag. Tinggi tanaman diamati satu minggu sekali hingga lima minggu.

Pada umur lima MST tanaman jagung dipanen. Akar dibersihkan dari tanah yang menempel. Bobot basah bagian atas tanaman (tajuk) dan boot akar ditimbang. Sampel tanaman dikeringkan dalam oven pada suhu $60{ }^{\circ} \mathrm{C}$ selama 48 jam. Setelah itu, tanaman ditimbang bobot keringnya. Analisis efisiensi agronomi didapatkan melalui rumus berikut (Chuan et al., 2013) :

Efisiensi agronomi $=$ bobot kering biomassa perlakuan-bobot kering biomassa kontrol jumlah hara yang ditambahkan

Pengukuran kadar $\mathrm{N}$ tanaman dilakukan dengan metode Kjeldahl, sedangkan $\mathrm{P}$ dan $\mathrm{K}$ tanaman dengan metode pengabuan basah $\left(\mathrm{HNO}_{3}+\mathrm{HClO}_{4} 2: 1\right)$. Kadar hara tanaman dikonversi menjadi serapan hara tanaman dengan mengalikan hasil kadar hara dengan bobot kering tanaman.

Data tinggi tanaman, bobot tanaman, dan serapan hara tanaman diuji dengan sidik ragam (ANOVA) menggunakan perangkat lunak Microsoft Excel 2013. Apabila hasil berbeda nyata, data diuji dengan menggunakan uji Duncan Multiple Range Test (DMRT) pada taraf $\alpha=5 \%$.

Tabel 1. Dosis pemberian pupuk pada setiap satuan percobaan

\begin{tabular}{|c|c|c|c|c|c|c|c|c|c|c|}
\hline \multirow{2}{*}{ Perlakuan } & Urea & SP-36 & $\mathrm{KCl}$ & Pukan & $\mathrm{POH}^{1}$ & Urea & SP-36 & $\mathrm{KCl}$ & Pukan & $\mathrm{POH}^{1}$ \\
\hline & \multicolumn{5}{|c|}{-------Bahan pupuk (ppm)-------- } & \multicolumn{5}{|c|}{------Bahan pupuk (g polibag ${ }^{-1}$ )------ } \\
\hline Kontrol & 0 & 0 & 0 & 5,000 & 0 & 0 & 0 & 0 & 25.0 & 0 \\
\hline $50 \% \mathrm{NPK}^{2}$ & 62 & 38 & 38 & 5,000 & 0 & 0.31 & 0.19 & 0.19 & 25.0 & 0 \\
\hline $100 \% \mathrm{NPK}^{3}$ & 144 & 76 & 76 & 5,000 & 0 & 0.62 & 0.38 & 0.38 & 25.0 & 0 \\
\hline $0 \% \mathrm{NPK}+\mathrm{POH}$ & 0 & 0 & 0 & 5,100 & 10 & 0 & 0 & 0 & 25.5 & 0.05 \\
\hline $50 \% \mathrm{NPK}+\mathrm{POH}^{2}$ & 62 & 38 & 38 & 5,100 & 10 & 0.31 & 0.19 & 0.19 & 25.5 & 0.05 \\
\hline $100 \% \mathrm{NPK}+\mathrm{POH}^{3}$ & 144 & 76 & 76 & 5,100 & 10 & 0.62 & 0.38 & 0.38 & 25.5 & 0.05 \\
\hline
\end{tabular}

Keterangan : 1) $\mathrm{POH}=$ Pupuk organik hayati, 2) Kandungan $\mathrm{N}, \mathrm{P}_{2} \mathrm{O}_{5}$, dan $\mathrm{K}_{2} \mathrm{O}$ pada pupuk NPK 50\% masing-masing sebesar : 27.9 ppm, 13.7 ppm, dan 22.8 ppm, 3) Kandungan $\mathrm{N}_{2} \mathrm{P}_{2} \mathrm{O}_{5}$, dan $\mathrm{K}_{2} \mathrm{O}$ pada pupuk NPK 100\% masing-masing sebesar : 55.8 ppm, 27.4 ppm, dan 45.6 ppm. 


\section{HASIL DAN PEMBAHASAN}

\section{Tinggi Tanaman}

Hasil sidik ragam menunjukkan bahwa kombinasi perlakuan pupuk organik hayati $(\mathrm{POH})$ dan NPK tidak berpengaruh nyata terhadap tinggi jagung pada sampai umur lima MST pada taraf nyata 5\% (Tabel 2). Hasil ini sesuai dengan penelitian Setiyowati (2011) yang menunjukkan tinggi jagung yang diberi perlakuan $\mathrm{POH}+$ NPK $50 \%$ mampu menyamai tinggi jagung perlakuan Kompos + NPK 100\%. Perlakuan POH + NPK 50\% dapat mensubstitusi 50\% kebutuhan pupuk NPK. POH mengandung bakteri Azotobacter, Azospirillum, dan mikroba pelarut fosfat. Mikroba tersebut selain meningkatkan ketersediaan hara juga menghasilkan hormon auksin dan giberelin yang mampu memacu pertumbuhan tanaman (Babalola, 2010; Cassan dan Diaz-Zorita, 2016). Giberelin memicu perkecambahan dan pemanjangan batang yang mampu merangsang pertumbuhan tinggi tanaman. Sementara itu, auksin memengaruhi tinggi tanaman melalui pemanjangan sel, pembentukan jaringan tumbuhan, mengatur dominasi apikal, dan respon terhadap rangsangan cahaya (Taiz dan Zeiger, 2002). Pengaruh substitusi pupuk kimia dengan $\mathrm{POH}$ terhadap tinggi jagung pada 5 MST disajikan pada Gambar 1.

\section{Bobot Kering Tanaman}

Hasil sidik ragam menunjukkan bahwa kombinasi perlakuan pupuk organik hayati $(\mathrm{POH})$ dan NPK tidak berpengaruh nyata terhadap bobot kering jagung pada sampai umur lima MST pada taraf nyata 5\%. Walaupun demikian, perlakuan $\mathrm{POH}$ menghasilkan bobot kering akar lebih berat daripada tanpa $\mathrm{POH}$ pada semua taraf dosis NPK. Peningkatan bobot akar semakin besar apabila POH dikombinasikan dengan pupuk NPK, namun bobot kering akar pada perlakuan POH + NPK $100 \%$ lebih rendah dibandingkan $\mathrm{POH}+\mathrm{NPK} 50 \%$. Menurut Van der Heijden et al. (2008), fungsi kerja mikrob fungsional dalam memobilisasi hara kurang efektif dalam kondisi kaya nutrisi.

Hasil penelitian menunjukkan bahwa kombinasi perlakuan $\mathrm{POH}$ dengan pupuk kimia menghasilkan bobot kering total yang lebih berat daripada perlakuan tanpa $\mathrm{POH}$ (Tabel 3). Bobot kering jagung yang diberi pupuk $\mathrm{POH}+$ $50 \%$ (NPK) memberikan hasil bobot kering total yang sama dengan perlakuan pemberian pupuk $100 \%$ (NPK). Hal ini menunjukkan bahwa pemberian $\mathrm{POH}$ yang dilakukan dalam percobaan ini mampu menggantikan 50\% kebutuhan NPK tanaman.

Pemberian pupuk NPK yang dikombinasikan dengan pupuk organik hayati (kompos yang diperkaya pupuk hayati) mampu meningkatkan bobot biomassa jagung dibandingkan perlakuan lainnya, baik akar maupun tajuk (Setiyowati, 2011; Larsen et al., 2017). Selain itu, hormon auksin dan giberelin yang dihasilkan oleh Azotobacter dan Azospirillum berperan dalam pembelahan dan pemanjangan sel (Taiz dan Zeiger, 2002; Babalola, 2010; Cassan dan Diaz-Morita, 2016). Keberadaan hormon tersebut menyebabkan bobot kering pada tanaman yang diberikan $\mathrm{POH}$ semakin meningkat.

\section{Serapan Hara Tanaman}

Serapan hara merupakan hasil perkalian dari kadar total unsur hara dengan bobot kering biomassa tanaman yang menunjukkan banyaknya unsur hara yang diserap oleh biomassa tanaman. Hasil sidik ragam menunjukkan bahwa kombinasi perlakuan POH dan NPK tidak berpengaruh nyata terhadap serapan hara $\mathrm{N}, \mathrm{P}$, dan $\mathrm{K}$ jagung pada taraf nyata $5 \%$. Pengaruh perlakuan kombinasi NPK dan $\mathrm{POH}$ terhadap serapan hara $\mathrm{N}, \mathrm{P}$, dan $\mathrm{K}$ jagung disajikan pada Tabel 4. Aktivitas bakteri Azotobacter dan Azospirillum yang terkandung dalam $\mathrm{POH}$ mampu memacu inisiasi dan pertumbuhan akar. Hal ini memacu semakin luasnya jaringan perakaran, sehingga hara yang dapat diserap dari tanah semakin meningkat (Jarell dan Beverly, 1981).

Tabel 2. Pengaruh substitusi pupuk kimia dengan $\mathrm{POH}$ terhadap tinggi jagung ${ }^{1}$

\begin{tabular}{|c|c|c|c|c|c|c|}
\hline \multirow{2}{*}{ Kode } & \multirow{2}{*}{ Perlakuan $^{2}$} & \multicolumn{5}{|c|}{ Tinggi tanaman $(\mathrm{cm})$} \\
\hline & & $1 \mathrm{MST}$ & $2 \mathrm{MST}$ & $3 \mathrm{MST}$ & $4 \mathrm{MST}$ & $5 \mathrm{MST}$ \\
\hline B0F0 & Kontrol & 15.9 & 35.9 & 41.4 & 45.5 & 55.1 \\
\hline $\mathrm{B} 0 \mathrm{~F} 1$ & NPK $50 \%{ }^{2}$ & 16.5 & 37.3 & 45.4 & 51.7 & 62.4 \\
\hline $\mathrm{B} 0 \mathrm{~F} 2$ & NPK $100 \%{ }^{2}$ & 17.6 & 38.8 & 48.3 & 57.3 & 65.3 \\
\hline B1F0 & $\mathrm{POH}$ & 16.1 & 37.3 & 47.2 & 52.0 & 56.7 \\
\hline B1F1 & $\mathrm{POH}+\mathrm{NPK} 50 \%{ }^{2}$ & 17.6 & 38.0 & 47.0 & 51.4 & 61.3 \\
\hline B1F2 & $\mathrm{POH}+\mathrm{NPK} 100 \%{ }^{2}$ & 17.4 & 39.0 & 49.0 & 56.5 & 68.5 \\
\hline
\end{tabular}

Tabel 3. Pengaruh substitusi pupuk kimia dengan $\mathrm{POH}$ terhadap bobot kering jagung ${ }^{1}$

\begin{tabular}{|c|c|c|c|c|c|c|c|}
\hline \multirow[b]{2}{*}{ Kode } & \multirow[b]{2}{*}{ Perlakuan $^{2)}$} & \multicolumn{3}{|c|}{ Bobot $\left(\mathrm{g}\right.$ tanaman $\left.^{-1}\right)$} & \multicolumn{3}{|c|}{ Bobot $(\%)$} \\
\hline & & \multicolumn{3}{|c|}{--------g tanaman ${ }^{-1}-------$} & Akar & uk & Total \\
\hline B0F0 & Kontrol & 0.51 & 1.90 & 2.41 & 100.0 & 100.0 & 100.0 \\
\hline B0F2 & NPK $100 \%{ }^{2}$ & 0.80 & 2.92 & 3.73 & 157.1 & 153.7 & 154.5 \\
\hline $\mathrm{B} 1 \mathrm{~F} 0$ & $\mathrm{POH}$ & 1.17 & 1.91 & 3.08 & 128.8 & 100.5 & 127.6 \\
\hline $\mathrm{B} 1 \mathrm{~F} 1$ & $\mathrm{POH}+\mathrm{NPK} 50 \%^{2}$ & 1.19 & 2.53 & 3.72 & 133.2 & 133.2 & 154.1 \\
\hline $\mathrm{B} 1 \mathrm{~F} 2$ & $\mathrm{POH}+\mathrm{NPK} 100 \%^{2}$ & 0.88 & 3.05 & 3.93 & 172.2 & 160.5 & 162.8 \\
\hline
\end{tabular}

Keterangan : ${ }^{1}$ Berdasarkan hasil ANOVA dengan taraf nyata $5 \%$, dan ${ }^{2}$ Dosis pupuk NPK $50 \%=\mathrm{Urea}^{125} \mathrm{~kg} \mathrm{ha}^{-1} ; \mathrm{SP}_{-36} 75 \mathrm{~kg}^{-1}$; dan $\mathrm{KCl}^{-15} \mathrm{~kg}$ ha ${ }^{-1}$; $\mathrm{NPK}^{-1}$ $100 \%=$ Urea $250 \mathrm{~kg} \mathrm{ha}^{-1} ; \mathrm{SP}-36150 \mathrm{~kg} \mathrm{ha}^{-1}$; dan $\mathrm{KCl} 150 \mathrm{~kg} \mathrm{ha}^{-1}$; dan POH $=20 \mathrm{~kg} \mathrm{ha}^{-1}$ 


\section{Serapan N}

Hasil penelitian menunjukkan bahwa kombinasi perlakuan POH dengan NPK menghasilkan serapan N lebih tinggi dibandingkan dengan perlakuan tanpa $\mathrm{POH}$, namun hal tersebut tidak terjadi pada taraf dosis NPK 100\% (Tabel 4). Meningkatnya serapan $\mathrm{N}$ jagung akibat penambahan POH hingga taraf dosis NPK 50\% disebabkan oleh adanya mikrob penambat $\mathrm{N}$ bebas yang mampu memfiksasi $\mathrm{N}$, yaitu Azospirillum dan Azotobacter. Kemudian, $\mathrm{N}$ bebas tersebut diubah menjadi ammonium yang dipicu oleh aktivitas enzim nitrogenase (Santi et al., 2013). Proses ini menjadi penting karena $\mathrm{NH}_{4}{ }^{+}$merupakan bentuk $\mathrm{N}$ yang dapat diserap tanaman. Hal tersebut menyebabkan bakteri tersebut mampu hidup dan meningkatkan ketersediaan $\mathrm{N}$ pada jagung. Menurut Setiyowati (2011) dan Kalhapure et al. (2013), pemberian Azotobacter pada jagung mampu meningkatkan serapan $\mathrm{N}$ jagung. Pada dua penelitian tersebut, serapan hara $\mathrm{N}$ semakin meningkat apabila pemberian Azotobacter dikombinasikan dengan pupuk NPK serta bahan organik. Di sisi lain, ketersediaan hara yang diduga sudah mencukupi kebutuhan jagung menyebabkan serapan N pada perlakuan POH + NPK 100\% tidak seefektif perlakuan NPK $100 \%$.

\section{Serapan $\mathbf{P}$}

Hasil penelitian menunjukkan kombinasi perlakuan NPK dan POH menghasilkan serapan P lebih tinggi daripada kombinasi perlakuan tanpa POH (Tabel 4). Hal ini menunjukkan pemberian $\mathrm{POH}$ efektif pada semua taraf dosis pupuk NPK untuk meningkatkan serapan P. Peningkatan serapan $\mathrm{P}$ seiring dengan peningkatan dosis pemupukan $\mathrm{P}$. $\mathrm{POH}$ ini mengandung mikroba pelarut fosfat yang tidak saja mampu melarutkan fosfat yang tidak larut menjadi tersedia bagi tanaman tetapi juga mampu meningkatkan pengambilan P oleh tanaman. Meningkatnya serapan $\mathrm{P}$ jagung disebabkan oleh adanya mikrob pelarut fosfat. Mikrob ini mampu melarutkan P dalam bentuk anorganik dan organik. Pelarutan P organik terjadi melalui enzim fosfatase, fitase, fosfonatase, dan C-P liase. Hasil pelarutan berupa ion $\mathrm{HPO}_{4}^{-2}$ dan $\mathrm{H}_{2} \mathrm{PO}_{4}^{-}$yang tersedia bagi tanaman (Sharma et al., 2013). Setiyowati (2011) melaporkan bahwa kombinasi penambahan pupuk hayati berisi Azotobacter, Azospirillum, Bacillus subtilis, dan Pseudomonas beteli dengan kompos mampu meningkatkan serapan P jagung yang diberikan pupuk NPK.

\section{Serapan K}

Hasil penelitian menunjukkan kombinasi perlakuan NPK dan POH menghasilkan serapan K yang lebih tinggi daripada kombinasi perlakuan tanpa $\mathrm{POH}$, namun hal tersebut tidak terjadi pada taraf dosis NPK 100\% (Tabel 4). Peningkatan serapan pada taraf dosis tanpa NPK dan NPK 50\% disebabkan oleh berkembangnya jaringan perakaran setelah penambahan $\mathrm{POH}$. Di sisi lain, ketersediaan hara yang diduga sudah mencukupi kebutuhan jagung menyebabkan serapan $\mathrm{K}$ pada perlakuan $\mathrm{POH}+$ NPK $100 \%$ tidak seefektif perlakuan NPK $100 \%$ Peningkatan serapan $\mathrm{K}$ seiring dengan peningkatan dosis pemupukan K. Hal ini menandakan pemupukan K secara kimia masih diperlukan untuk mendukung pertumbuhan jagung. Setiyowati (2011) melaporkan bahwa perlakuan kombinasi pupuk kompos yang diperkaya pupuk hayati dengan pupuk NPK dapat meningkatkan serapan K pada jagung, namun pengaruhnya tidak nyata.

\section{Efisiensi Agronomi}

Efisiensi agronomi adalah sebuah metode penentuan rekomendasi pemupukan berdasarkan peningkatan hasil per unit hara dari pupuk yang ditambahkan (Chuan et al., 2013). Penentuan efisiensi agronomi dilakukan terhadap kombinasi perlakuan NPK dan $\mathrm{POH}$ yang meliputi efisiensi pemberian $\mathrm{N}, \mathrm{P}$, dan $\mathrm{K}$ terhadap bobot kering tajuk jagung. Efisiensi agronomi N, $\mathrm{P}$, dan $\mathrm{K}$ disajikan pada Gambar 2.

Berdasarkan Gambar 2, efisiensi agronomi kombinasi perlakuan POH dan NPK lebih tinggi daripada perlakuan NPK secara tunggal pada dosis NPK 50\% dan NPK $100 \%$. Perlakuan POH + NPK 50\% memiliki efisiensi agronomi tertinggi dibandingkan perlakuan lainnya, sedangkan perlakuan NPK $100 \%$ paling rendah. Berdasarkan efisiensi agronomi, perlakuan $\mathrm{POH}+\mathrm{NPK}$ $50 \%$ lebih efisien dibandingkan perlakuan NPK 50\% dan NPK $100 \%$. Dengan demikian, pupuk POH mampu meningkatkan efisiensi pemupukan NPK jagung pada fase vegetatif. Peningkatan dosis pupuk NPK berbanding lurus dengan penurunan efisiensi agronomi (Chuan et al., 2013; $\mathrm{Xu}$ et al., 2014). Unsur P memiliki efisiensi agronomi tertinggi dibandingkan $\mathrm{N}$ dan $\mathrm{K}$. Efisiensi agronomi yang tinggi menunjukkan respon pemupukan yang tinggi, begitu pula sebaliknya (Chuan et al., 2013; Xu et al., 2014). Hal ini menunjukkan bahwa jagung lebih responsif pada pemberian $\mathrm{P}$ melalui pupuk kombinasi NPK dan $\mathrm{POH}$ dibandingkan $\mathrm{K}$ dan $\mathrm{N}$.

Tabel 4. Pengaruh substitusi pupuk kimia dengan POH terhadap serapan ${ }^{1}$

\begin{tabular}{|c|c|c|c|c|}
\hline \multirow{2}{*}{ Kode } & \multirow{2}{*}{ Perlakuan ${ }^{2}$} & \multicolumn{3}{|c|}{ Serapan Hara (mg polibag $\left.{ }^{-1}\right)$} \\
\hline & & $\mathrm{N}$ & $\mathrm{P}$ & $\mathrm{K}$ \\
\hline B0F0 & Kontrol & $63.00 \pm 21.26$ & $12.37 \pm 5.69$ & $83.41 \pm 30,88$ \\
\hline B0F1 & NPK $50 \%{ }^{2}$ & $73.40 \pm 37.31$ & $12.45 \pm 7.25$ & $112.24 \pm 55,16$ \\
\hline B0F2 & NPK $100 \%^{2}$ & $93.84 \pm 35.32$ & $16.45 \pm 5.46$ & $149.17 \pm 68,61$ \\
\hline B1F0 & $\mathrm{POH}$ & $64.32 \pm 22.68$ & $12.65 \pm 3.99$ & $89.08 \pm 32,23$ \\
\hline $\mathrm{B} 1 \mathrm{~F} 1$ & $\mathrm{POH}+\mathrm{NPK} 50 \%{ }^{2}$ & $77.96 \pm 67.56$ & $13.59 \pm 7.12$ & $117.27 \pm 93,28$ \\
\hline B1F2 & $\mathrm{POH}+\mathrm{NPK} 100 \%^{2}$ & $80.49 \pm 07.99$ & $17.46 \pm 4.88$ & $139.46 \pm 24,75$ \\
\hline
\end{tabular}

Keterangan : ${ }^{1}$ Berdasarkan hasil ANOVA dengan taraf nyata 5\%, dan ${ }^{2}$ Dosis pupuk NPK 50\% = Urea $125 \mathrm{~kg} \mathrm{ha}^{-1} ; \mathrm{SP}-3675 \mathrm{~kg} \mathrm{ha}^{-1} ;$ dan KCl $75 \mathrm{~kg} \mathrm{ha}^{-1} ; \mathrm{NPK}$ $100 \%=$ Urea $250 \mathrm{~kg} \mathrm{ha}^{-1} ;$ SP-36 $150 \mathrm{~kg} \mathrm{ha}^{-1} ;$ dan KCl $150 \mathrm{~kg} \mathrm{ha}^{-1} ;$ dan POH $=20 \mathrm{~kg} \mathrm{ha}^{-1}$ 


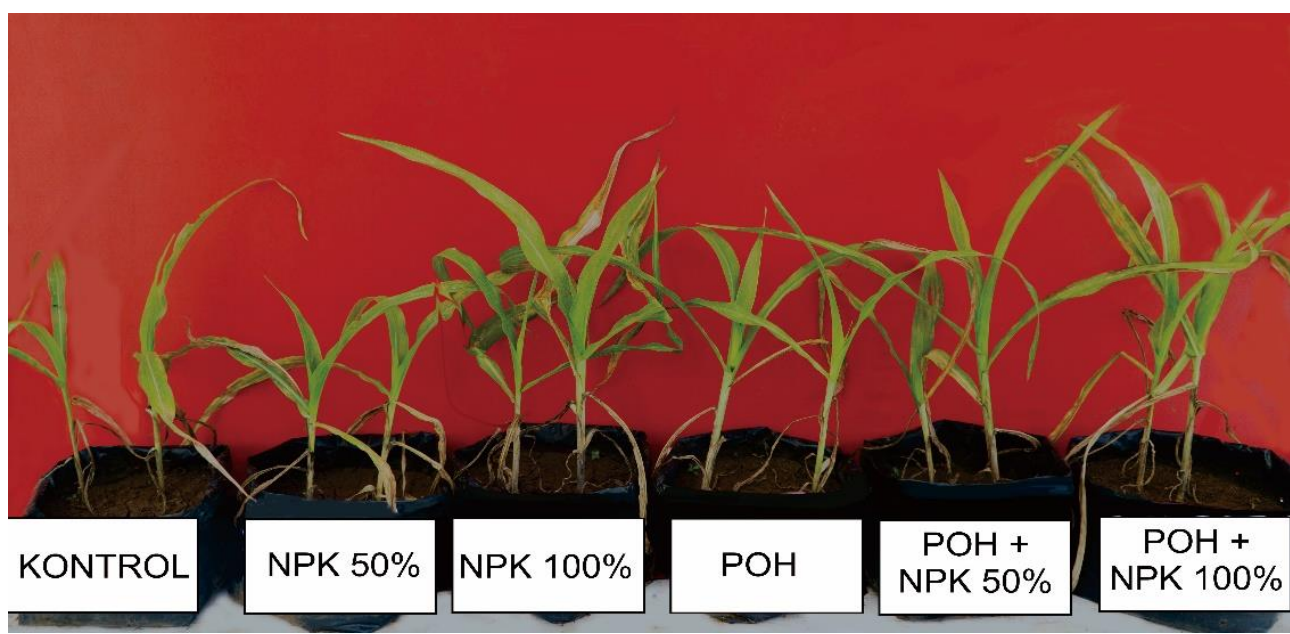

Gambar 1. Pengaruh substitusi pupuk kimia dengan POH terhadap tinggi jagung pada 5 MST
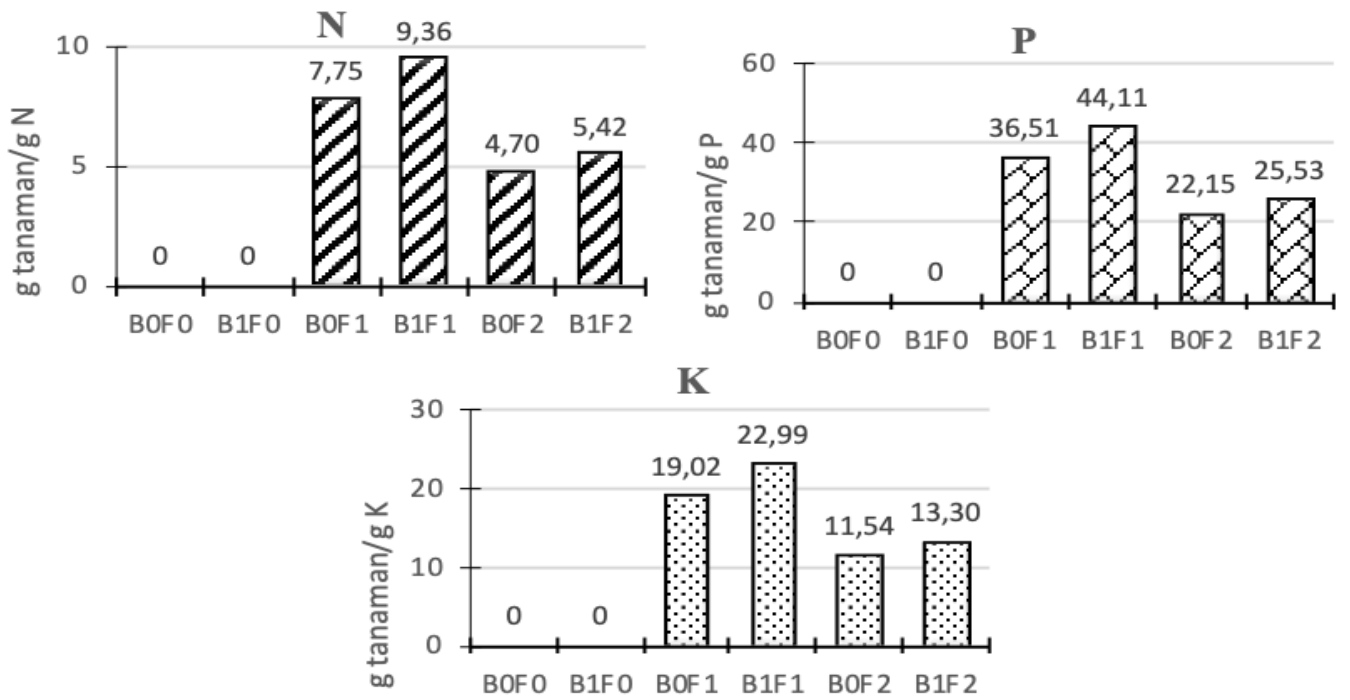

Gambar 2. Pengaruh substitusi pupuk kimia dengan $\mathrm{POH}$ terhadap efisiensi agronomi N, P, dan $\mathrm{K}$ jagung

\section{SIMPULAN}

Pemberian pupuk organik hayati mampu mensubstitusi $50 \%$ kebutuhan NPK tanpa mengurangi pertumbuhan jagung, meningkatkan serapan hara $\mathrm{N}, \mathrm{P}$, dan $\mathrm{K}$, serta meningkatkan efisiensi agronomi pemupukan NPK tanaman jagung.

\section{DAFTAR PUSTAKA}

Anas, I. 2016. Pentingnya Bioteknologi Tanah dalam Mencapai Sistem Pertanian yang Berkelanjutan, Orasi Ilmiah Guru Besar IPB. Bogor, Indonesia : 9 April, 2016, Bogor, Indonesia. IPB Press, Bogor.

Babalola, O.O. 2010. Beneficial bacteria of agricltural importance. Biotechnology Letter, 32 : 1559-1570.

Cassan, F. and M. Diaz-Zorita. 2016. Azospirillum sp. In current agriculture: From the laboratory to the field. Soil Biology and Biochemistry, 117-130.

Chuan, L., P. He, M.F. Pampolino, A.M. Johnston, J. Jin, X. $\mathrm{Xu}$, S. Zao, S. Qiu and W. Zhou. 2013. Establishing a scientific basis for fertilizer recommendations for wheat in China : Yield response and agronomic efficiency. Field Crops Research, $140: 1-8$.
Jarell, W.M. and R.B. Beverly. 1981. The dilution effect in plant nutrition studies. Advances in Agronomy, 34: 197-224.

Kalhapure, A.H., B.T. Shete and M.B. Dhonde. 2013. Integrated nutrient management in Maize (Zea mays L.) for increasing production with sustainability. International Journal of Agriculture and Food Science Technology, 4(3): 195-206.

Larsen, J., H. Pineda-Sánchez, I. Delgado-Arellano, V. Castellano-Morales, L. Carreto-Montoya and J. Villegas-Moreno. 2017. Interactions between microbial plant growth promoters and their effects on maize growth performance in different mineral and organic fertilization scenarios. Rhizosphere, 3: $75-81$.

Li, H., W. Feng, X. He, Z. Ping, H. Gao, N. Sun and M. Xu. 2017. Chemical fertilizers could be completely replaced by manure to maintain high maize yield and soil organic carbon (SOC) when SOC reaches a threshold in the Northeast China Plain. Journal of Interactive Agriculture, 16(4): 937 - 946.

Santi, C., D. Bogusz and C. Franche. 2013. Biological nitrogen fixation in non-legume plants. Annals of Botany, 111: 743-767. 
Savci, S. 2012. Investigation of effect of chemical fertlizers on environment. APCBEE Proceedia, 287-292.

Setiyowati. 2011. Penambahan mikrob pemacu tumbuh untuk meningkatkan kualitas pupuk organik, serapan hara, pertumbuhan, serta produksi padi gogo dan jagung [Tesis]. IPB, Bogor.

Sharma, S.B., R.Z. Sayyed, M.H. Trivedi and T.A. Gobi. 2013. Phosphate solubilizing microbes: Sustainable approach for managing phosphorus deficiency in agricultural soils. SpringerPlus, 2: $587-601$.
Taiz, L. and E. Zeiger. 2002. Plant Physiology. $3^{\text {rd }}$ ed. Sinauer Associates, Sunderland, United States.

Van der Heijden, M.G.A., R.D. Bardgett and N.M. Van Straalen. 2008. The unseen majority: soil microbes as drivers of plant diversity and productivity in terrestrial ecosystems. Ecology Letters, 11: 296 310.

Xu, X., P. He, M.F. Pampolino, A.M. Johnston, S. Qiu, S. Zhao, L. Chuan and W. Zhou. 2014. Fertilizer recommendation for maize in China based on yield response and agronomic efficiency. Field Crops Research, 157: 27-34. 